\title{
Colour patterns in Early Devonian cephalopods from the Barrandian Area: Taphonomy and taxonomy
}

\author{
Vojtěch Turek \\ Acta Palaeontologica Polonica 54 (3), 2009: 491-502 doi: http://dx.doi.org/10.4202/app.2007.0064
}

Five cephalopod specimens from the Lower Devonian of Bohemia (Czech Republic) preserve colour patterns. They include two taxonomically undeterminable orthoceratoids and three oncocerid nautiloids assigned to the genus Ptenoceras. The two fragments of orthocone cephalopods from the lowest Devonian strata (Lochkovian, Monograptus uniformis Zone) display colour patterns unusual in orthoceratoids. They have irregular undulating and zigzag strips that are preserved on counterparts of adapertural regions of specimens flattened in shale, despite their original aragonitic shell having been completely dissolved. These are probably the result of the proteinous pigment inside the shell wall, being substituted during diagenesis by secondary minerals leaving only an altered trace of the original shell. Orthoceratoids from sediments unsuitable for preservation of this feature discussed here thus demonstrate an exceptional case of preservation of colour patterns, not only within Devonian cephalopods but also within other Devonian molluscs. Three specimens of Ptenoceras that preserve colour patterns come from younger Lower Devonian strata. Oblique spiral adaperturally bifurcating bands are preserved in $P$. alatum from the Pragian and zigzags in $P$. nudum from the Dalejan. Juvenile specimen of Ptenoceras? sp. from the Pragian exhibits highly undulating transversal bands-a pattern resembling colour markings in some Silurian oncocerids. Dark grey wavy lines observed on the superficially abraded adapical part of a phragmocone of nautiloid Pseudorutoceras bolli and interpreted formerly to be colour markings are here reinterpreted as secondary pigmented growth lines. Other Devonian fossils including a single brachiopod and several gastropods from the Barrandian Area with preserved colour patterns are mentioned. Variety of cephalopod colour patterns, their taxonomic significance, function and significance for palaeoecological interpretation, palaeoenvironmental conditions favouring colour pattern preservation and systematic affiliation of taxa with colour pattern preserved are discussed.

Key words: Cephalopoda, Nautiloidea, colour pattern, Devonian, Bohemia, Czech Republic.

Vojtěch Turek [vojtech.turek@nm.cz], Národní muzeum, Praha, Přírodovědecké muzeum, paleontologické oddělení, Václavské náměstí 68, 11579 Praha 1, Czech Republic. 
This is an open-access article distributed under the terms of the Creative Commons Attribution License (for details please see creativecommons.org), which permits unrestricted use, distribution, and reproduction in any medium, provided the original author and source are credited.

Forif Full text $(491.2 \mathrm{kB})$ 